SHORT COMMUNICATIONS

\title{
Polysulfide compounds as inhibitors of the key base excision repair enzymes
}

\author{
M. M. Kutuzov, A. L. Zakharenko, M. V. Sukhanova, S. N. Khodyreva, \\ T. M. Khomenko ${ }^{1}$, K. P. Volcho ${ }^{1}$, N. F. Salakhutdinov ${ }^{1}$, O. I. Lavrik
}

Novosibirsk Institute of Chemical Biology and Fundamental Medicine, Siberian Branch of the Russian Academy of Sciences 8, Akademika Lavrentieva Ave., Novosibirsk, Russian Federation, 630090

${ }^{1}$ N. N. Vorozhtsov Novosibirsk Institute of Organic Chemistry, Siberian Branch of the Russian Academy of Sciences 9, Akademika Lavrentieva Ave., Novosibirsk, Russian Federation, 630090

lavrik@niboch.nsc.ru; anvar@nioch.nsc.ru

\begin{abstract}
Aim. To increase the capacity of antitumor therapy based on DNA damage it is important to minimize the repair of DNA lesions that can be achieved by inhibiting the activity of key DNA repair enzymes. To this end several benzopentathiepine and benzo [1,3] dithiol derivatives were synthesized and tested as inhibitors of the key base excision repair (BER) enzymes, PARP1, DNA polymerase $\beta$, and APE1. Methods. The procedure of synthesis of several new compounds was developed. The inhibitory capacity of the compounds was estimated by comparison of the enzyme activities in specific tests in the presence of compounds versus their absence. Results. Benzopentathiepine derivative bearing trifluoromethyl group at the 1-st position was shown to be a weak inhibitor of PARP1. Cyclic substituents at the 1-st position attached through amide bond bring about moderate enhancement of pol $\beta$ inhibition. Each studied substituent at the 1-st position considerably increases the inhibition of APE1-catalyzed hydrolysis of AP sites as compared to parent compound. Conclusions. Several new inhibitors of $B E R$ enzymes were revealed. The directions for further modification of compounds to improve their inhibitory activity were found out.
\end{abstract}

Keywords: DNA polymerase $\beta$, poly(ADP-ribose)polymerase 1, apurinic/apyrimidinic endonuclease 1, polysulfide, pentathiepine, inhibitor.

Introduction. The base excision repair (BER) enzymes repair alkylated, oxidative and IR-induced damage of DNA. Poly(ADP-ribose)polymerase (PARP1), DNA polymerase $\beta$ (pol $\beta$ ) and apurinic/apyrimidinic endonuclease 1 (APE1) are the key enzymes of BER process. These enzymes expression is often enhanced in tumor cells therefore their activity suppression may lead to apoptosis and sensitize to action of apoptosis inductors as it was shown for APE1 and PARP1 [1]. Sensitizing of tumor cells to chemotherapeutic agents and irradiation action by the BER enzymes inhibition is considered as perspective approach in oncotherapy [1].

Varacine analogs were chosen as candidates for the BER enzyme inhibitors on the basis of computer modeling and its known antitumor activity [2].

(C) Institute of Molecular Biology and Genetics, NAS of Ukraine, 2012
Materials and methods. Synthesis of varacine analogs. Compound 1 was synthesized from 4-chloro-3,5dinitrobenzotrifluoride using inexpensive reagents in a two-stage process, in accordance with the procedure proposed earlier [3]. Modification of compound 1 at the position 1 was conducted through corresponding acyl chlorides. Dithiol compounds $\mathbf{4}$ and $\mathbf{5}$ were synthesized from corresponding benzopentathiepines by interaction with methylene chloride. For the best of our knowledge compounds 2, 3, 3.HCl, 4 and 5 are new. Structures of the compounds were established using ${ }^{1} \mathrm{H},{ }^{13} \mathrm{C}$ and ${ }^{19} \mathrm{~F}$ NMR, and high-resolution HPLC-MS.

Enzymes. Human recombinant PARP1, rat recombinant pol $\beta$ and human recombinant APE1 were prepared according to $[4,5,6]$, respectively. The enzyme activity tests for pol $\beta$, APE1 and PARP1 were carried out as described previously $[5,6,7]$, respectively. 
Inhibitory characteristics of compounds in specific reactions catalyzed by PARP1, DNA polymerase $\beta$ and APE1 (see Figure)

\begin{tabular}{c|c|c|c} 
Designation & $\begin{array}{c}\text { PARP1*, \% } \\
1 \mathrm{mM}\end{array}$ & $\begin{array}{c}\text { DNA polymerase } \beta^{*}, \% \\
\text { @ } 1 \mathrm{mM}\end{array}$ & $\begin{array}{c}\text { APE1*, \% } \\
2 \mathrm{mM}\end{array}$ \\
\hline $\mathbf{1}$ & 93 & 86 & 76 \\
$\mathbf{2}$ & 83 & 36 & 15 \\
$\mathbf{3}$ & 81 & 33 & 10 \\
$\mathbf{3} \cdot \mathbf{H C l}$ & 93 & 42 & 12 \\
$\mathbf{4}$ & 77 & 57 & 13 \\
$\mathbf{5}$ & 77 & 93 & 8.5 \\
$\mathbf{6}$ & 37 & 34 & 23 \\
7 & 18 & 72 & 20 \\
\hline
\end{tabular}

* Residual activity of the enzyme in the presence of compounds (at defined concentration) versus control.
Comparative analysis of compounds bearing different substituents revealed a trend of influence of the substituent structure on the inhibitory properties in PAR synthesis; these data may be useful in further design of potential inhibitors.

Piperidine and pyrrolidine substituents at the 1-st position attached via amide bond, induced marked enhancement of inhibitory properties of compounds in DNA synthesis catalyzed by pol $\beta$; RA of pol $\beta$ dropped from $86 \%$ for parent pentathiepine 1 to $33-36 \%$ for new derivatives (Table). On the contrary, transition from pentathiepines to dithiols results in a decrease or even loss of inhibitory activity testifying to importance of pentathiepine cycle in the compounds for inhibition of pol $\beta$.<smiles>Nc1cc(C(F)(F)F)cc2c1SSSSS2</smiles><smiles>O=C(CN1CCCC1)Nc1cc(C(F)(F)F)cc2c1SSSSS2</smiles><smiles>O=C(CN1CCCCC1)Nc1cc(C(F)(F)F)cc2c1SSSSS2</smiles><smiles>O=C(CN1CCCCC1)Nc1cc(C(F)(F)F)cc2c1SSSSS2</smiles><smiles>O=C(CN1CCCC1)Nc1cc(C(F)(F)F)cc2c1SCS2</smiles><smiles>O=C(CN1CCCCC1)Nc1cc(C(F)(F)F)cc2c1SCS2</smiles><smiles>CC(=O)Nc1cc(C(F)(F)F)cc2c1SSSSS2</smiles><smiles>O=S(=O)(Nc1cc(C(F)(F)F)cc2c1SSSSS2)OC(F)(F)F</smiles>

Structural formulas of new derivatives (see Table)
Results and discussion. The influence of 8-trifluoromethyl-1,2,3,4,5-benzopentathiepine-6-amine (compound 1 , Table) and its derivatives on the activity of key BER enzymes was studied. The effect of the compounds on DNA polymerase activity of pol $\beta$, autopoly(ADP-ribosyl)ation of PARP1 and AP site cleavage by APE1 were analyzed. The results are shown in Table. An inhibitory potential of compounds was estimated as residual activity (RA) of the enzymes in specific activity tests in the presence of an indicated concentration of compound versus its absence.

Among pentathiepines bearing the trifluoromethyl group at the 5-th position, the compound 7 with $\mathrm{NHCOCF}_{3}$ group at the 1-st position proved to be the most efficient in PARP1 inhibition (RA is $18 \%$ ). Replacement of $\mathrm{NHCOCF}_{3}$ group to bulky substituents results in a decrease of the inhibitory activity (RA is 83 , 81 and $93 \%$ for the compounds $\mathbf{2}, \mathbf{3}$ and hydrochloride of $\mathbf{3}$, respectively).
In the case of APE1, introduction of substituents to the 1-st position also results in enhancement of inhibitory characteristics (RA decreases from $76 \%$ to $8.5-$ $23 \%$ (Table); and cyclic substituents are more efficient compared to acyclic ones in their influence on the inhibitory characteristics (RA is $8.5-15 \%$ and $20-23 \%$, respectively). It should be noticed that for APE1 unlike pol $\beta$ presence of the pentathiepine cycle in derivatives is not critical for their inhibitory properties since pentathiepine and dithiol derivatives with the same substituent at the 1-st position bring about equal inhibition.

It is worthy of notice that destabilization of pentathiepine cycle caused by introduction of pyrrolidine or piperidine substituents (the compounds $\mathbf{2}$ and $\mathbf{3}$ ) render their properties to intrinsic ones of naturally occurring varacines and consequently enhancing the likelihood of manifestation of their antitumor activity.

Conclusions. Thus, the specific regularities were revealed for each BER enzyme. For instance, the acyc- 
lic substituents at the 1-st positions seem to be promising for PARP1 inhibitors. In the case of pol $\beta$ the dithiol derivatives are ineffective as compared with pentathiepines, while the dithiol and pentathiepine derivatives are comparable in APE1 inhibition. As a whole, the data obtained allow us to propose the directions of further compound modification for the selective inhibition of certain base excision repair stages.

Acknowledgments. This work was supported by RFBR 11-04-12099 and Interdisciplinary project of Siberian Branch of the Russian Academy of Sciences N 51.

М. М. Кутузов, А. Л. Захаренко, М. В. Суханова, С. Н. Ходирева, Т. М. Хоменко, К. П. Волчо, Н. Ф. Салахутдинов, О. І. Лаврик

Полісульфідні сполуки як інгібітори ключових ферментів ексцизійної репарації основ

Резюме

Мета. Щоб підвищити ефективність протипухлинної терапї, заснованої на пошкодженнях ДНК, важливим є мінімізувати усу нення цих пошкоджень, чого можна досягти, пригнічуючи активність ключових ферментів репарації ДНК. Для цуього синтезовано $i$ протестовано декілька похідних бензопентатієпіну $i$ бензо[1, 3]дитіолу як інгібітори ключових ферментів ексцизійної репараціі основ (ЕРО), ПАРП1, ДНК полімерази $\beta$ і АРЕ1. Методи. Розроблено процедури синтезу низки нових сполук. Інгібіторні властивості сполук очінювали, порівнюючи ферментативну активність у специфічних тестах за присутності і відсутності потенційних інгібіторів. Результати. Похідне бензопентатієпіну, яке містить трифторметильну групу у першому положенні, виявилося м'яким інгібітором ПАРП1. Приєднання до першого положення через амідний зв 'язок ичиклічних замісників призводить до деякого посилення інгібування ДНК-полімерази $\beta$. Усі вивчені замісники у першому положенні значно збільшують інгібування розщеплення АPсайтів, яке каталізується АРЕ1, порівняно з вихідними сполуками. Висновки. Виявлено декількі інгібіторів ферментів ЕРО. Визначено також шляхи подальшої модифікачї сполук для покращення їхніх інгібіторних характеристик.

Ключові слова: ДНК-полімераза $\beta$, полі(АДФ-рибоза)полімераза 1, апуринова/апіримідинова ендонуклеаза 1, полісульфід, пентатієпін, інгібітор.

М. М. Кутузов, А. Л. Захаренко, М. В. Суханова, С. Н. Ходырева, Т. М. Хоменко, К. П. Волчо, Н. Ф. Салахутдинов, О. И. Лаврик

Полисульфидные соединения как ингибиторы ключевых ферментов эксцизионной репарации оснований

\section{Резюме}

Цель. Чтобы повысить эффективность противоопухолевой терапии, основанной на повреждениях ДНК, важно минимизировать исправление этих повреждений, что может быть достигнуто за счет подавления активности ключевых ферментов репараичи ДНК. Для этого были синтезированы и протестированы несколько производных бензопентатиепина и бензо[1,3]дитиола в качестве ингибиторов ключевых ферментов эксиизионной репарации оснований (ЭРО), ПАРП1, ДНК полимеразы $\beta$ и АРЕ1. Ме- тоды. Разработаны процедуры синтеза ряда новых соединений. Ингибиторные способности соединений оценивали, сравнивая ферментативную активность в специфических тестах в присутствии и в отсутствие потенциальных ингибиторов. Результаmbl. Производное бензопентатиепина, несущее трифторметильную группу в первом положении, оказалось мягким ингибитором ПАРП1. Присоединение к первому положению через амидную связь циклических заместителей приводит к некоторому усилению ингибирования ДНК-полимеразы $\beta$. Все изученнье заместители в первом положении значительно увеличивают ингибирование расщепления АР-сайтов, катализируемого АРE1, по сравнению с исходным соединением. Выводы. Обнаружено несколько новых ингибиторов ферментов ЭРО. Выявлены также пути дальнейтей модификации соединений для улучшения их ингибиторных характеристик.

Ключевые слова: ДНК-полимераза $\beta$, поли(АДФ-рибоза)полимераза 1, апуриновая/апиримидиновая эндонуклеаза 1, полисульфид, пентатиепин, ингибитор.

\section{REFERENCES}

1. Reed A. M., Fishel M. L., Kelley M. R. Small-molecule inhibitors of proteins involved in base excision repair potentiate the antitumorigenic effect of existing chemotherapeutics and irradiation // Future Oncol.-2009.-5, N 5.-P. 713-726.

2. Davidson B. S., Molinski T. F., Barrows L. R., Ireland C. M. Varacin: a novel benzopentathiepin from Lissoclinum vareau that is cytotoxic toward a human colon tumor // J. Am. Chem. Soc.1991.-113, N 12.-P. 4709-4710.

3. Khomenko T. M., Tolstikova T. G., Bolkunov A. V., Dolgikh M. P., Pavlova A. V., Korchagina D. V., Volcho K. P., Salakhutdinov N. F. 8-(Trifluoromethyl)-1,2,3,4,5-benzopentathiepin-6-amine: novel aminobenzopentathiepine having in vivo anticonvulsant and anxiolytic activities // Lett. Drug Des. Discov.-2009.-6, N 6.P. 464-467.

4. Sukhanova M. V., Khodyreva S. N., Lavrik O. I. Poly(ADP-ribose) polymerase-1 inhibits strand-displacement synthesis of DNA catalyzed by DNA polymerase beta // Biochemistry (Mosc).2004.-69, N 5.-P. 558-568.

5. Drachkova I. A., Petruseva I. O., Safronov I. V., Zakharenko A. L., Shishkin G. V., Lavrik O. I., Khodyreva S. N. Reagents for modification of protein-nucleic acids complexes. II. Site-specific photomodification of DNA-polymerase beta complexes with primers elongated by the dCTP exo-N-substituted arylazido derivatives // Bioorg. Khim.-2001.-27, N 3.-P. 197-204.

6. Lebedeva N. A., Khodyreva S. N., Favre A., Lavrik O. I. AP endonuclease 1 has no biologically significant 3 ' $\rightarrow$ 5'-exonuclease activity // Biochem. Biophys. Res. Commun.-2003.-300, N 1.P. 182-187.

7. Zakharenko A. L., Sukhanova M. V., Khodyreva S. N., Novikov F. N., Stroilov V. S., Nilov D. K., Chilov G. G., Shviadas V. K., Lavrik $O$. I. Improved procedure of the search for poly(ADP-Ribose) polymerase-1 potential inhibitors with the use of the molecular docking approach // Mol. Biol. (Mosk).-2011.-45, N 3.P. 565-569. 